KOLOM ILMIAH

Social Humaniora

\title{
PENGARUH ETOS KERJA DAN RESTRUKTURISASI ORGANISASI TERHADAP PRODUKTIVITAS KARYAWAN: STUDI KASUS PADA PT CITRA AGRO LOMBOK SEBAGAI PENGELOLA RPH BANYUMULEK
}

\author{
Ivon Arisanti \\ Magister Manajemen Sumber Daya Manusia Fakultas Ekonomi Universitas Mataram \\ Email: Ivon2109@gmail.com
}

\begin{tabular}{|c|c|}
\hline \multicolumn{2}{|r|}{ ABSTRAK } \\
\hline $\begin{array}{l}\text { Diterima: } \\
\text { Januari } 2019\end{array}$ & $\begin{array}{l}\text { Penelitian ini bertujuan untuk mengetahui signifikansi pengaruh etos kerja } \\
\text { dan restrukturisasi organisasi terhadap produktivitas karyawan (studi kasus } \\
\text { pada PT Citra Agro Lombok (PT CAL), pengelola RPH Banyumulek, Kediri, } \\
\text { Lombok Barat). Pengumpulan data dilakukan dengan cara mengumpulkan } \\
\text { data-data primer dan sekunder PT CAL. Kuisioner dibagikan kepada } 40\end{array}$ \\
\hline $\begin{array}{l}\text { Diterbitkan: } \\
\text { Februari } 2019\end{array}$ & $\begin{array}{l}\text { orang karyawan meliputi seluruh tingkatan manajemen. Metode } \\
\text { pengumpulan data menggunakan Metoda Kuantitatif dengan menggunakan } \\
\text { Skala Likert dan analisis yang digunakan adalah Analisa Path atau yang } \\
\text { lebih dikenal dengan analisa jalur. }\end{array}$ \\
\hline $\begin{array}{l}\text { Kata Kunci: } \\
\text { Etos kerja, } \\
\text { restrukrisasi organisas, } \\
\text { produktivitas } \\
\text { karyawan }\end{array}$ & 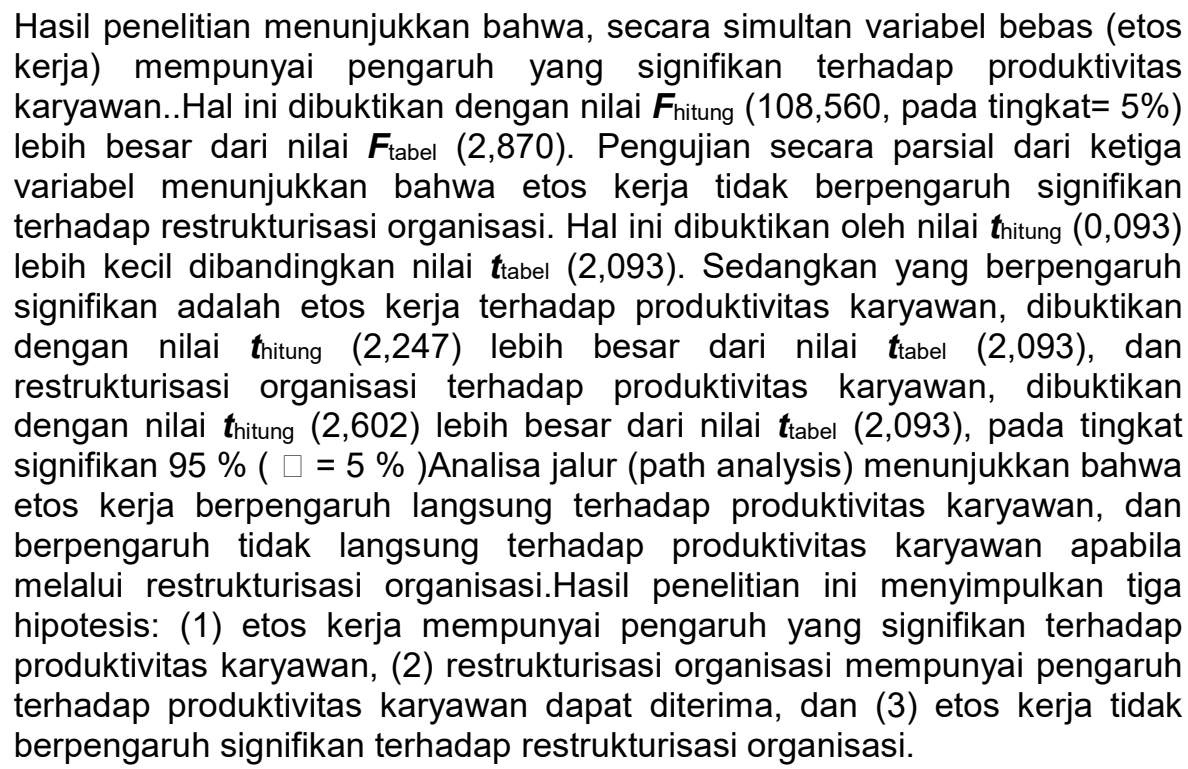 \\
\hline
\end{tabular}

\section{PENDAHULUAN}

Pada umunya para pengelola RPH salah satunya PT CAL menyatakan bahwa manusia adalah faktor terpenting dalam pengembangan dan kemajuan bisnis. Tentu hal ini benar karena tanpa adanya manusia maka suatu organisasi tidak dapat berjalan dengan semestinya. Manusia memiliki potensi insani yang terpendam dan menjadi kunci keberhasilan suatu organisasi karena potensi insani ini merupakan sumber kekuatan perusahaan yang paling berharga dan sangat menentukan keunggulan suatu organisasi. Sukses tidaknya suatu organisasi akan bergantung pada aktivitas dan kretivitas sumber daya manusianya. Untuk itu, hal hal utama yang harus diperhatikan oleh manajer suatu perusahaan adalah bagaimana membangkitkan gairah kerja karyawan. Karyawan akan termotivasi dalam meningkatkan kinerjanya dengan didorong oleh perilaku karyawan yang positif dalam menciptakan citra perusahaan yang baik di mata konsumen maupun produsen

Pada dasarnya organisasi atau perusahaan adalah sebuah upaya manusia, dan seperti yang dikatakan oleh Peter Drucker (1997) tujuan utama organisasi adalah membuat kekuatan manusia menjadi efektif dan kelemahannya menjadi tidak relevan. Masa depan adalah milik organisasi 
bunglon, yaitu sebuah organisme yang sedemikian harmonisnya dengan lingkungan sehingga ia dapat beradaptasi dengan sangat mudah dan cepat. Menciptakan semangat kerja karyawan agar menjadi lebih produktif adalah dengan membenahi pangkal masalahnya yaitu memunculkan etos kerja, karena hal inilah yang merupakan akar yang dapat mendorong karyawan untuk mencintai pekerjaaannya.

Menurut Diester, dkk (1982) etos kerja digambarkan sebagai semangat bekerja. Siapa yang etos kerjanya tinggi akan selalu bergairah/bersemangat dalam menjalani kegiatan kerja yang telah diputuskan menjadi bagian dari kehidupannya. Orang-orang yang memiliki etors kerja tinggi akan tertanam dalam dirinya prinsip tanggung jawab dan kemandirian. Terpartri dalam jiwanya slogan "hari ini harus lebih baik dari hari kemarin" yang sumbernya adalah ajaran agama. Prinsip dari ajaran agama (Islam) akan menjadi keperibadian masa kini.

Filipo (1980) berpendapat bahwa peningkatkan etos kerja dapat dilakukan melalui motivasi kerja, penerapan sistem imbalan, partisipasi pegawai, sistem dan prosedur kerja serta hubungan kerja dengan situasi dan kondisi organisasi. Hasilnya akan mampu meningkatkan kinerja organisasi secara optimal dan telah terbukti menjadi suatu konsep yang sangat bermanfaat guna analisis perilaku dalam organisasi. Organisasi akan mampu bertahan, berdasarkan pada orientasi strategis memperhatikan kedudukan, tugas pokok dan fungsi orgnisasi dalam menghadapi lingkungan usaha yang mengalami perubahan sangat cepat. Salah satu orientasi starategis yang dapat diimplementasikan adalah melakukan 'restrukturisasi' organisasi, yaitu upaya dengan cara meningkatkan efisiensi dan produktivitas yang pada akhirnya organisasi mampu menjadi lebih baik dan berdaya guna serta mampu meningkatkan kualitas pelayanan kepada masyarakat pelanggan (Sedarmayanti, 2000:3).

Petingnya restrukturisasi organisasi bukan hanya pada kegiatan 'bongkar pasang' organisasi, tetapi lebih kepada manajemen Sumber Daya Manusia (SDM) berbasis kompetensi yang menggambarkan suatu hubungan ketenagakerjaan sehingga karyawan termotivasi untuk meningkatkan produktivitas ke arah perilaku yang produktif, di mana karyawan dapat memberikan satu kontribusi yang berguna bagi perkembangan dana kemajuan perusahaan.

Salah satu prinsip dasar dari produktivitas adalah keinginan atau usaha setiap manusia untuk selalu meningkatkan mutu kehidupan dan penghidupannya. Pandangan ini yang mengandung arti filosofi ini memberi arti dan semangat yang cukup mendalam. Pandangan ini juga memungkinkan setiap orang yang memahami untuk memandang kerja, baik secara individual maupun berkelompok dalam suatu perusahaan sebagai suatu prioritas, mengutamakan bekerja dengan mengacu pada unsur efisiensi dan efektivitas sebagai sumber teknis dari konsep produktivitas (Sedarmayanti, 2001).

Dalam rangka mengembangkan pemahaman tentang restrukturisasi organisasi, maka diambil satu perusahaan yang telah melakukan restrukturisasi orgasnisasi dan personil sebagai bahan analisis dalam penelitian ini, yakni perusahaan PT Citra Agro Lombok atau biasa disingkat PT CAL. PT CAL sendiri bergerak dalam bidang usaha produksi dan perdagangan daging sapi/kerbau beku. Produksi daging sapi/kerbau beku perusahaan ini berpedoman pada standar daging yang telah ditetapkan oleh Pemerintah Indonesia, yaitu daging "ASUH", daging sapi/kerbau yang Aman, Sehat, Utuh dan serta Halal. PT CAL adalah pengelola RPH Banyumulek menggantikan PT Royal Kencana Mulya ( PT RKM ), yang merupakan pengelola pertama dari RPH Banyumulek, sejak ditandatanganinya perjanjian kerja sama antara PT CAL dan PT RKM melalui akte No. 3 pada Notaris Lia Gandasaputra, SH., tanggal 14 januari 2004. Perjanjian kerjasama ini dilakukan karena PT RKM tidak mampu lagi melaksanakan kewajibannya selaku pengelola RPH Banyumulek seperti yang tertera pada Kontrak ProduksiNo:524/1086/Kesmavet/VII/2002, tanggal 31 juli 2002. Pergantian pengelola $\mathrm{RPH}$ Banyumulek ini telah disetujui oleh Dinas Peternakan Provinsi Nusa Tenggara Barat.

Selama tahun 2004 PT CAL mengalami permasalahan berupa harga beli sapi/kerbau yang lebih tinggi dan harga jual daging sapi/kerbau beku yang lebih rendah dari business plan yang telah disusun. Hal ini berdampak pada jumlah produksi yang jauh di bawah jumlah yang telah ditetapkan. Pada sisi yang lain tenaga produksi dan manajer yang tersedia adalah telah ditetapkan sesuai dengan rencana produksi. Hal ini mengakibatkan beban/biaya operasional yang tinggi dan ketidakefisienan tenaga kerja. Di samping itu pula terdapat beban lain yang sifatnya eksternal berupa fluktuasi harga beli sapi/kerbau dan kondisi pasar daging beku yang tidak stabil, yang mengakibatkan semakin beratnya kerja manajemen untuk menselaraskan komponen-komponen perusahaan untuk mencapai tujuan perusahaan.

Untuk menyelesaikan masalah intenal perusahaan, kemudian dilakukanlah restrukturisasi organisasi dan personil dengan maksud untuk mengurangi beban/biaya operasioanl, meningkatkan efisiensi sumber daya manusia, memudahkan pengambilan keputusan dan juga untuk meningkatkan daya saing perusahaan. Dengan kata lain PT CAL memandang SDM sebagai Human Capital (sebagai aset intelektual perusahaan, pusat inovasi, pembentuk karakter dan citra perusahaan serta pembentuk daya saing 
perusahaan ). Dalam rangka menciptakan etos kerja yang tinggi para karyawan dapat memberikan kontribusinya dalam rangka meningkatkan produktivitasnya dan membawa perusahaan menuju ke arah yang lebih baik yang salah satunya mengembangkan Human Capital dengan menciptakan perilaku karyawan yang unggul, tangguh dan bermartabat.Dengan adanya restrukturisasi ini, tenaga kerja berkurang dari semula 69 orang menjadi hanya 40 orang, dengan perincian yaitu jumlah manajer dari 5 orang dikurangi menjadi hanya 2 orang, jumlah tenaga produksi dari 59 orang menjadi hanya 33 orang, sedang tenaga kerja yang jumlahnya tetap adalah direktur sebanyak 2 orang, tenaga administrasi sebanyak 1 orang dan Satpam sebanyak 2 orang.

Berdasarkan hal tersebut di atas, maka PT CAL berusaha untuk menjadikan perusahaan ini menjadi perusahaan yang dapat bersaing di pasar regional dan dapat menguasai pasar dengan membuat kekuatan manusia menjadi efektif dan berusaha untuk meminimalkan kelemahannya.

\section{LANDASAN TEORI}

\section{Etos Kerja}

Dalam Websters World University Dictionary ( 1965 : 331 ) dijelaskan etos adalah sifat dasar atau karakter yang merupakan kebiasaan, watak bangsa atau ras. Etos berasal dari kata Yunani, ethos, artinya ciri, sifat ,atau kebiasaan, adat istiadat, atau juga kecendrungan moral, pandangan hidup yang dimiliki seseorang, suatu kelompok orang atau bangsa. Sedangkan menurut Nurcholish Madjid ( 1995 : 410 ) etos adalah karakter dan sikap , kebiasaan serta kepercayaan dan seterusnya yang bersifat khusus tentang seorang individu atau sekelompok manusia. Dan dari kata etos terambil pula perkataan " etika" yang merujuk pada makna "akhlak" atau bersifat akhlaqiy, yaitu kualitas esensial seseorang atau suatu kelompok manusia termasuk suatu bangsa.

Etos kerja yang dimiliki oleh seseorang atau kelompok masyarakat akan menjadi sumber pendorong utama bagi perbuatannya. Apabila dikaitkan dengan situasi kehidupan manusia yang sedang "membangun", maka etos kerja yang tinggi akan dijadikan sebagai prasyarat yang mutlak, yang harus ditumbuhkan dalam kehidupan itu. Karena hal itu akan membuka pandangan dan sikap kepada manusianya untuk menilai tinggi terhadap kerja keras dan sungguh-sungguh, sehingga dapat mengikis sikap kerja yang asal-asalan tidak berorientasi terhadap mutu atau kualitas yang semestinya.

Menurut Ahmad Janan Asifudin ( 2004 : 38 ) indikasi - indikasi orang yang beretos kerja tinggi pada umumnya memiliki sifat-sifat antara lain : 1) Aktif dan suka bekerja keras ,2) Bersemangat dan hemat, 3) Tekun ,4) Kreatif, 5 ) Jujur,disiplin dan bertanggung jawab, 6 ) Mandiri 7,) Rasional serta mempunyai visi yang jauh ke depan 8), Percaya diri, 9) Sederhana,tabah dan ulet, 10) Sehat, jasmani dan rohani

\section{Restrukturisasi Organisasi}

Strategi restrukturisasi, di Indonesia secara yuridis formal telah memiliki landasan yang kuat yakni dengan dikeluarkannya Keputusan Menteri Keuangan Republik Indonesia Nomor 740/KMK.00/1989 tentang Peningkatan Efisiensi dan Produktivitas Badan Usaha Milik Negara ( BUMN ). Keputusan ini menjelaskan bahwa yang disebut Restrukturisasi Organisasi adalah " tindakan untuk meningkatkan efisiensi dan produktivitas organisasi melalui perubahan status hukum, organisasi dan pemilikan saham”. Dalam Bab II pasal 2, dinyatakan pula bahwa :

1. Peningkatan efisiensi dan produktivitas BUMN dilakukan melalui restrukturisasi organisasi

2. Restrukturisasi organisasi meliputi : a) Perubahan status hukum BUMN yang lebih menunjang pencapaian maksud dan tujuan organisasi, b) Kerjasama operasi atau kontrak manajemen dengan pihak ketiga, c ) Konsolidasi atau merger, d) Pemecahan badan usaha, e ) Penjualan saham melalui pasar modal, f) Penjualan secara langsung, g) Pembentukan organisasi patungan ( Sedarmayanti $2000: 59$ )

Menurut Robbins ( 1996 :421 ) mengemukakan sebuah model untuk mengelola perubahan organisasi yang dinyatakan bahwa perubahan pada suatu bidang organisasi kemungkinan akan mendorong timbulnya kekuatan-kekuatan baru untuk perubahan lainnya.

Suatu alasan yang dapat digunakan bagi organisasi yang memikirkan untuk membuat perubahan dalam struktur adalah melalui restrukturisasi, Hitt,Ireland dan Hoskisson ( 1997:237 ) mendefinisikan restrukturisasi sebagai perubahan komposisi bisnis perusahaan dan atau struktur keuangan. Pemicu restrukturisasi adalah kinerja yang buruk, sekaligus koreksi terhadap overdifersifikasi. Karena itu restrukturisasi menjadi suatu tindakan yang strategis dan penting. Lebih lanjut Hitt, Ireland dan Hoskisson mengemukakan tiga strategi restrukturisasi, yaitu downsizing, downsoping dan laveraged buyouts seperti yang tampak digambar bawah ini.

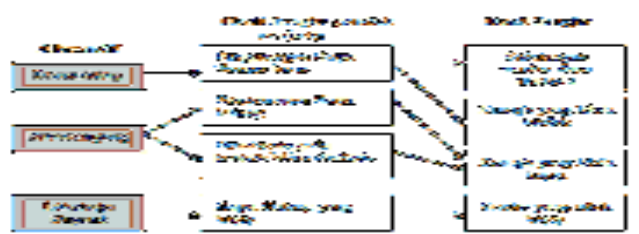

Sumber : Hitt,Ireland dan Hoskisson ( 1997 :241) 


\section{PRODUKTIVITAS}

Indikator produktivitas dikembangkan dan dimodifikasi dari pemikiran Gilmore ( 1974) dan Fromm (1975) dalam Sedarmayanti ( 2001: 79 ) tentang individu yang produktif, yaitu : 1) Tindakan konstruktif, 2) Percaya pada diri sendiri, 3) Bertanggung jawab, 4) Memiliki rasa cinta terhadap pekerjaan, 5) Mempunyai pandangan ke depan, 6 ) Mampu mengatasi persoalan dan dapat menyesuaikan diri dengan lingkungan yang berubah-ubah,7) Mempunyai kontribusi positif terhadap lingkungannya, 8) Memiliki kekuatan untuk mewujudkan potensinya.

Gilmore (1974) dalam sedarmayanti (2001:80) mengemukakan bahwa orang yang produktif adalah :

"Who is making tangible and significant cintribution in his choosen field, who is imaginative,perceptive, and innovative in his approach to life problems and to accomplishment of his own goal (creativity), and who is at the same both responsible and responsive in his relationship with other"

Dari uraian tersebut,Gilmore menekankan kontribusi yang positif dari diri seseorang terhadap lingkungannya dimana dia berada. Dengan adanya tindakan yang konstruktif,imaginatif,kreatif dari individu dalam suatu organisasi,maka diharapkan produktivitas organisasi akan meningkat.

Pribadi yang produktif menggambarkan potensi, persepsi dan kreativitas seseorang yang senantiasa ingin menyumbangkan kemampuan agar bermanfaat bagi diri dan lingkungannya.Jadi,orang yang produktif adalah orang yang dapat memberi sumbangan yang nyata dan berarti bagi lingkungan sekitarnya,imaginatif,dan inovatif dalam mendekati persoalan hidupnya serta mempunyai kepandaian ( kreatif) dalam mencapai tujuan hidupnya.Pada saat yang bersamaan orang seperti ini selalu bertanggung jawab dan responsif dalam hubungannya dengan orang lain.Pegawai seperti ini merupakan aset organisasi, yang selalu berusaha meningkatkan diri dalam organisasinya dan akan menunjang pencapaian produktivitas organisasi.

\section{METODOLOGI}

Penelitian menggunakan model penelitian asosiatif. Penelitian asosiatif bertujuan untuk mengetahui hubungan atau bentuk keterkaitan lainnya antara satu atau lebih variabel. Pengumpulan data menggunakan data sekunder dari PT CAL yang relevan dengan penelitian ini dan pembagian kuisioner kepada para responden. Populasi penelitian berjumlah 69 karyawan dengan sampel sebanyak 40 orang setelah diadakan restrukturisasi. Berikut ini table komposisi jumlah karyawan PT CAL.
Tabe 1

\begin{tabular}{|l|l|c|}
\hline No & \multicolumn{1}{|c|}{ Unit Kerja } & $\begin{array}{c}\text { Jumlah } \\
\text { Karyawan } \\
\text { (orang ) }\end{array}$ \\
\hline 1. & Direktur & 1 \\
\hline 2. & Manager & 2 \\
\hline 3. & Slotter ( Penyembelihan ) & 6 \\
\hline 4. & $\begin{array}{l}\text { Deboning Pemisahan } \\
\text { daging dari tulang })\end{array}$ & 11 \\
\hline 5. & Tenaga tekhnis & 1 \\
\hline 6. & Staff Keuangan & 1 \\
\hline 7. & Marketing & 2 \\
\hline 8. & Mekanik & 2 \\
\hline 9. & Gudang & 3 \\
\hline 10 & Kandang & 2 \\
\hline 11. & Satpam & 3 \\
\hline 12. & Limbah & 1 \\
\hline 13. & Cleaning Service & 1 \\
\hline 14. & Gardening & 2 \\
\hline 15. & Driver & $\mathbf{4 0}$ \\
\hline & Jumlah & \\
\hline
\end{tabular}

1. Komposisi jumlah karyawan PT CAL

Sumber : Bagian Personalia PT CAL (2006)

Pengukuran variabel, baik variabel bebas maupun variabel terikat menggunakan "Skala Likert". Dengan skala yang menggunakan skor interval 5 (lima) yaitu skor nilai tertinggi (sangat setuju ) adalah 5 dan skor nilai terendah (sangat tidak setuju) adalah 1 (satu). Demikian pula terhadap variabel terikat skor tertinggi dengan nilai 5 adalah sangat setuju dan skor terendah nilai 1 yaitu sangat tidak setuju. Dengan skala ini, responden diharapkan memberikan tanggan terhadap setiap pernyataan dengan memilih salah satu dari lima pilihan yang disediakan. Secara rinci pengukuran masing-masing variabel adalah sebagai berikut :

1. Variabel bebas ( Indevendent variabel); yaitu Etos Kerja

2. Variabel antara ; Restrukturisasi Organisasi,

3. Variabel tergantung ( Dependent variable); yaitu Produktivitas karyawan

Tekhnik analisis dalam penelitian ini disesuaikan dengan model analisis yang diajukan menurut Solimun (2002: 44) yaitu Path Analysis (Analisa Jalur) yang digunakan untuk menguji pengaruh langsung ( direct effec) dan pengaruh tidak langsung (indirect effect ) variabel bebas terhadap variabel terikat. Adapun persamaan regresinya adalah :

Untuk mengetahui pengaruh langsung dari variabel idevendent dan variabel dependent digunakan nilai koefisien jalur ( $\mathrm{p}$ ), yang perhitungannya diperoleh dari nilai $\beta 1$ - $\beta 5$ pada model persamaan yang ada dan setelah semua 
variabel ditransformasi ke variabel standar $\mathrm{Z}$ yang mempunyai nilai rata-rata distribusi $(\mu)=0$ dan varian $(\sigma 2)=1$, dengan rumus :

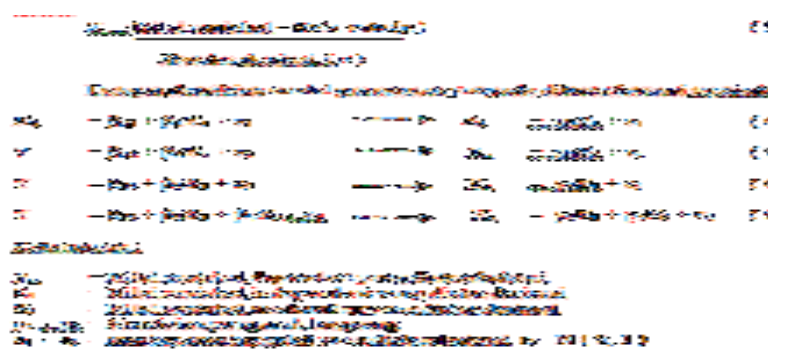

\section{HASIL DAN PEMBAHASAN}

Hasil penelitian menunjukkan bahwa secara simultan variabel bebas (etos kerja) mempunyai pengaruh yang signifikan terhadap produktivitas karyawan. Hal ini dibuktikan dengan nilai $\boldsymbol{F}_{\text {hitung }}$ $(108,560$, pada tingkat $=5 \%)$ lebih besar dari nilai $\boldsymbol{F}_{\text {tabel }}(2,870)$.

Pembahasan dalam penelitian ini mangacu pada maksud dan tujuan penelitian untuk memperoleh data yang menunjukkan gambaran tentang adanya pengaruh etos kerja dan restrukturisai organisasi terhadap produktivitas karyawan PT CAL. Uraian dalam pembahasan hasil penelitian ini tetap berpedoman pada hasil analisa data dan pengujian hipotesis statistik yang telah dilakukan dengan mengacu pada teori-teori yang menjelaskan rasionalitas hasil penelitian.

a. Diduga ada pengaruh etos kerja terhadap produktivitas karyawan untuk setiap jenjang jabatan pada PT CAL (Citra Agro Lombok ).

Menurut peneliti dengan adanya delapan etos kerja pandangan Jansen (1999) yang termuat dalam sebuah tulisan pada artikel Compas Cyber Media (KCM),selasa 06 september 2005,11:01 WIB. Tentang 8 etos pendongkrak gairah kerja,dikatakan bahwa etos kerja tentu akan berpengaruh kepada produktivitas karyawan karena produktivitas karyawan merupakan output dari etos kerja.Adapun 8 etos pendongkrak gairah kerja terdiri dari: 1) kerja adalah rahkmat, 2) kerja adalah amanah, 3) kerja adalah panggilan, 4) kerja adalah aktualisasi, 5) kerja adalah ibadah, 6) kerja adalah seni, 7) kerja adalah kehormatan, 8) kerja adalah pelayanan. Maka, pendongkrak gairah kerja yang paling menonjol adalah etos kerja: kerja adalah ibadah. Seseorang yang menganggap bahwa bekerja adalah ibadah merupakan seseorang yang memiliki etos kerja yang tinggi. Hal ini dikarenakan ibadah adalah segala sesuatu yang dijalankan dengan niat lurus karena Allah dan ikhtiar di jalan-Nya. Kita harus meluruskan niat untuk mengabdikan diri kepada Allah, demikian juga dengan caranya. Masalah rezki adalah urusan Allah. Untuk itu diperlukan kerja keras dengan cerdas dan ikhlas, dimana kita harus menanamkan standar pada diri kita, yaitu bekerja optimal dengan pemikiran yang cerdas. Ada orang yang bekerja dengan keras tetapi kurang menggunakan akalnya, akibatnya dia menjadi pekerja keras saja. Berdasarkan hal tersebut di atas, maka dengan diadakannya penelitian pada PT CAL ( Citra Agro Lombok ) akan dapat kita ketahui bahwasanya etos kerja berpengaruh terhadap produktivitas karyawan.Dengan adanya etos kerja yang merupakan bagian dari pemetaan motivasi maka timbullah etos kerja yang dikuatkan dengan skill, knowledge, ability dan sebaginya. Yang perlu kita ingat disini adalah bagaimana meningkatkan semangat kerja atau gairah kerja dengan berupaya memetakan motivasi kerja dalam konsep delapan etos kerja yang seperti diuraikan oleh Jansen tersebut. Sehingga secara otomatis produktivitas karyawan pun akan meningkat dan dapat memberikan kontribusi yang positif untuk perusahaan maupun untuk karyawan itu sendiri.Dengan adanya kesadaran produktivitas atau perilaku produktif yang ditimbulkan, maka perilaku karyawan pun akan mulai berubah. Perubahan yang terjadi diharapkan tidak bersifat sementara. Tapi bagaiman perubahan itu terjadi secara alami namun terus berkelanjutan

b. Berdasarkan hipotesis, maka dilakukan pengujian secara parsial ,sehingga didapatkan hasil berupa :

1. Pengujian secara parsial "Pengaruh etos kerja terhadap produktivitas karyawan untuk setiap jenjang jabatan pada PT CAL"

Menurut sedarmayanti (2000: 69) restrukturisasi, disamping akan mendorong dicapainya visi dan misi perusahaan,juga akan dapat meningkatkan produktivitas dan etos kerja. Dengan adanya restrukturisasi organisasi,maka perusahaan akan lebih mampu melakukan pemberdayaan karyawan sehingga produktivitas meningkat dan kualitas pelayanan meningkat pula.

Berdasarkan hasil penelitian di atas , pengaruh etos kerja terhadap produktivitas karyawan PT CAL menunjukkan hasil yang signifikan. Hal ini dikarenakan karyawan secara sadar mencintai pekerjaan mereka, 
mengingat lapangan kerja saat ini sangat terbatas dimana angka pengangguran masih sangat tinggi. Karyawan berupaya menggeluti pekerjaan yang mereka kerjakan sekarang sebagai bagian dari upaya memenuhi kebutuhan keluarga mereka.

2. Pengujian secara parsial " Pengaruh etos kerja terhadap restrukturisasi organisasi untuk setiap jenjang jabatan pada PT CAL"

Berdasarkan hasil penelitian pada PT CAL didapatkan bahwa pengaruh etos kerja terhadap restrukturisasi organisasi untuk setiap jenjang jabatan tidak berpengaruh signifikan. Hal ini dikarenakan gairah atau semangat kerja karyawan masih kurang. Karyawan cendrung menuntut adanya pemenuhan hak sesuai dengan keinginan mereka sehingga berpengaruh terhadap kulitas dan kuantitas hasil kerja mereka, dan tentu hal ini berpengaruh terhadap restrukturisasi organisasi yang sedang dijalankan oleh PT CAL dalam rangka peningkatan pendapatan perusahaan. Diharapkan karyawan memiliki etos kerja yang tinggi sehingga dapat menghasilkan output yang dapat menigkatkan pendapatan perusahaan. Sehingga dari hal inilah pelaksanaan restrukturisasi organisasi dapat berjalan dengan baik sesuai dengan visi dan misi organisasi.

Etos kerja karyawan PT CAL tidak berpengaruh signifikan terhadap restrukturisasi organisasi dikarenakan rekstrukturisasi organisasi di PT CAL didasarkan pada kebutuhan efisiensi perusahaan dalam rangka penghematan biaya operasional dan modal kerja. Di sisi lain restrukturisasi organisasi (pengurangan karyawan) akan berpengaruh negatif kepada karyawan pada awalnya karena timbul kekhawatiran munculnya rekstrukturisasi lanjutan yang akan memPHK mereka dan juga munculnya opini bahwa sebagian dari kebijakan ini didasarkan pada suka dan tidak suka. Tetapi pada akhirnya restrukturisasi justru meningkatkan produktifitas karyawan PT CAL.

PENUTUP

\section{KESIMPULAN}

1. Adanya pengaruh yang signifikan dari etos kerja terhadap produktivitas karyawan, hal ini dibuktikan dengan nilai $\mathrm{F}_{\text {hitung }}=$ 108,560 lebih besar dibandingkan $\mathrm{F}_{\text {tabel }}=2,87$.

2. Dari ketiga variabel baik itu etos kerja ( $\left.\mathrm{X}_{1}\right)$,restrukturisasi organisasi $\left(\mathrm{X}_{2}\right)$, dan produktivitas karyawan ( $\mathrm{Y})$, berdasarkan pengujian secara parsial didapatkan bahwa etos kerja ( $\left.X_{1}\right)$ tidak berpengaruh signifikan terhadap restrukturisasi organisasi $\left(\mathrm{X}_{2}\right)$, sedangakan yang berpengaruh signifikan adalah etos kerja $\left(\mathrm{X}_{1}\right)$ dengan produktivitas karyawan (Y), dan restrukturisasi organisasi $\left(\mathrm{X}_{2}\right)$ terhadap produktivitas karyawan (Y ).

3. Berdasarkan analisa jalur ( path analysis ) didapatkan bahwa etos kerja memiliki pengaruh langsung terhadap produktivitas ,dan memiliki pengaruh tidak langsung antara variabel etos kerja melalui resrtruturisasi organisasi terhadap produktivitas karyawan.

\section{SARAN}

1. Pengaruh etos kerja terhadap restrukturisasi organisasi menunjukkan tidak signifikan. Oleh sebab itu perlu diadakan penelitian lebih lanjut terhadap kegiatan yang sama pada lokasi yang berbeda.

2. Dalam rangka pencapaian restrukturisasi organisasi yang sejalan dengan visi dan misi perusahaan maka perlu disusun suatu strategi dalam hal pemberdayaan perusahaan dan sumber daya manusia yang tepat dalam upaya peningkatan produktivitas.

3. Para pimpinan maupun karyawan perlu membangun suatu koalisi yang solid dalam sebuah tim sehingga akan dapat meningkatkan dukungan terhadap restrukturisasi organisasi sejalan dengan peningkatan etos kerja dan produktivitas karyawan menjadi lebih produktif.

4. Menciptakan perilaku produktif karyawan yang berkelanjutan dengan lebih mengedepankan peningkatan semangat dan gairah 
kerja dengan mensinergikan kemampuan fisik,otak dan hati dengan benar sehingga etos kerja dapat lebih ditingkatkan.

\section{REFERENSI}

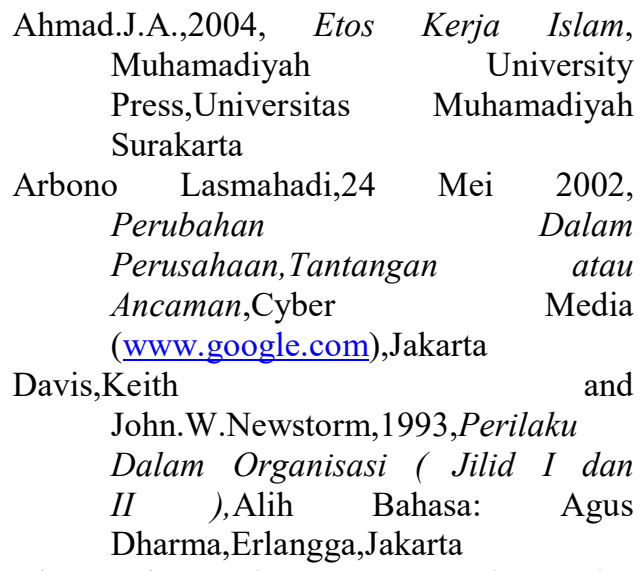

Diester,Nico Syukur,1982, Pengalaman dan Motivasi Beragama,Pengantar Psikologi Agama,Jakarta : Lappenas

Flippo.Edwin.B,1980,PersonnelManagemet, Fifth Edition,Mc Graw Hill Inc

Gibson,Ivanveinch,Donnelli,1996,Organisa si - Prilaku - Struktur, Proses, Jilid 1, Edisi Kedelapan, Bina Rupa Aksara,Jakarta

Harold J.Leavitt,1978, Managerial Physicology,Fourth Edition, The University of Chichago

Hasibuan, Malayu.SP.,2003, Manajemen Sumber Daya Manusia, PT Bumi Aksara, Jakarta

Hitt,Michael A.,R.Duane Ireland dan Robert.E.Hoskirson, 1997 , Manajemen Strategis: Menyongsong Era Persaingan dan Globalisasi,Terjemahan Erlangga, Jakarta
Lewis.M.A,et. Al, 1965, Websters World University Dictionary, Washinton DC;Publisher Company Inc.

Luthans,F.1992, Organizational Behaviour, Nint Edition McGraw Hill,Singapore

Mubyarto,dkk, 1991, Etos Kerja dan Kohesi Sosial Masyarakat Sumba,Rote,Sabu dan Timor Propinsi Nusa Tenggara Timur.Penerbit Aditya Media Yogyakarta,Yogyakarta.

Nasution.S, 2002, Metode Research,Edisi I, Cetakan 5, Penerbit Bumi Aksara,Jakarta.

Nizar.Moh,1988,

Metode Penelitian,Cetakan ke-3,Penerbit Ghalia Indonesia,Jakarta.

Peter F,Drucker, 1997, The Organization Of The Future; Organisasi Masa Depan, Penerbit PT Elex Media Komputindo Kelompok Gramedia,Jakarta

Robbins Stephen.P, 1996, Perilaku Organisasi,Konsep,Kontroversi, Aplikasi Jilid 1, Penerbit PT Prenhallindo, Jakarta

Sedarmayanti, 2000, Restrukturisasi dan Pemberdayaan Organisasi Untuk Menghadapi Dinamika Perubahan Lingkungan, Penerbit Mandar Maju, Bandung

Sedarmayanti,2001, Sumber Daua Manusia dan Produktivitas Kerja.Penerbit Mandar Jaya Bandung.

Smith,Kendall,Hullian,Luthans,2002,Organi zational Behaviour, Ninth Edition,McGraw Hill,Singapore

Solimun.Dr, 2002, Structural Equation Modeling Lisrel dan Amos, Penerbit Universitas Brawijaya,Malang

Winardi,1986, Manajemen Perilaku Organisasi, Prenada Media, Jakarta 